
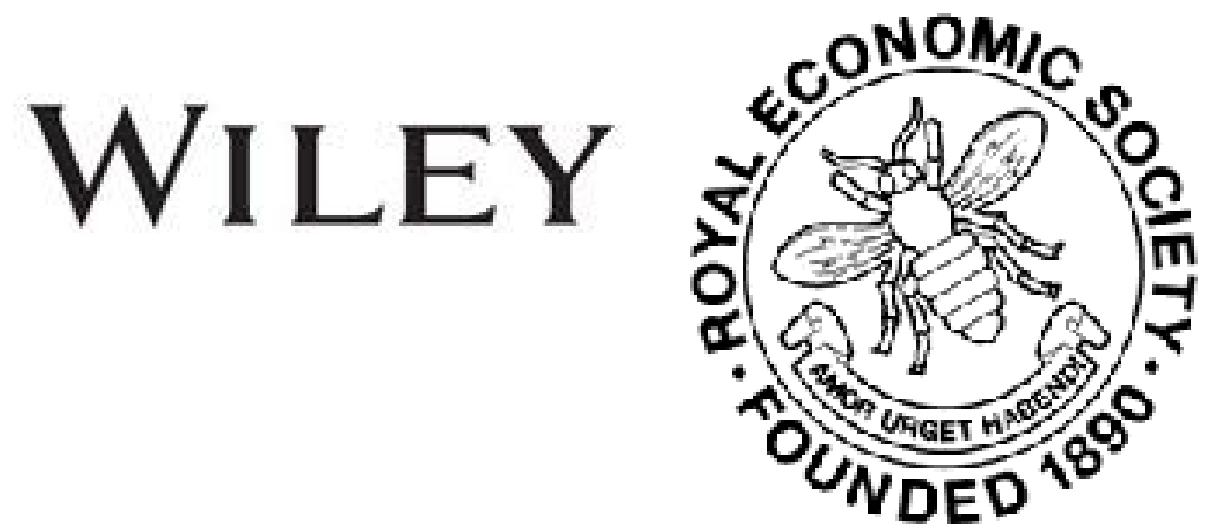

The Assessment of Weekly and Monthly Tenancies for Local Taxation Author(s): F. Oliver Lyons

Source: The Economic Journal, Vol. 20, No. 77 (Mar., 1910), pp. 13-22

Published by: Wiley on behalf of the Royal Economic Society

Stable URL: http://www.jstor.org/stable/2220576

Accessed: 27-06-2016 10:37 UTC

Your use of the JSTOR archive indicates your acceptance of the Terms \& Conditions of Use, available at

http://about.jstor.org/terms

JSTOR is a not-for-profit service that helps scholars, researchers, and students discover, use, and build upon a wide range of content in a trusted digital archive. We use information technology and tools to increase productivity and facilitate new forms of scholarship. For more information about JSTOR, please contact support@jstor.org.

Wiley, Royal Economic Society are collaborating with JSTOR to digitize, preserve and extend access to The Economic Journal 


\section{THE ASSESSMENT OF WEEKLY AND MONTHLY TENANCIES FOR LOCAL TAXATION.}

THE following may seem to refer more especially to the assessment of property within the metropolitan area where statutory maximum deductions are in force, but there is no reason why it should not, mutatis mutandis, be equally applicable everywhere. Scales for the assessment of weekly and monthly tenancies are very frequently constructed in a most haphazard manner, and without any regard to the universally recognised principles of valuation for rating. It is therefore proposed to show how scales may be framed with the least possible amount of trouble for which it may, at the same time, be claimed that they are based on correct principles. Hitherto it has been necessary to resort to the method of trial and error in order to find the correct gross and rateable values of such properties. This, especially where "extra upkeep" had to be taken into consideration, was a very difficult and cumbrous method; but its use is completely obviated by the formulæ and tables hereafter given.

The two propositions formulated below may be regarded as axiomatic when any class of weekly or monthly tenancy is under consideration. It will be observed that the second one is equivalent to saying that the rateable value per shilling of rent should gradually increase as the rent rises.

(1) In the vast majority of cases the annual rent which a tenant might reasonably be expected to pay for premises held, say, or a weekly tenancy, is not the sum of fifty-two weekly rents, but a somewhat lower figure.

(2) Both the deduction for maintenance and the contingency balance should be greatest in the case of the lowest rented houses, and should be gradually lessened as the rental values rise, except in the case of tenement houses-i.e., old houses let in separate floors or rooms.

In Smith $v$. Churchwardens of Birmingham (22. Q.B.D. 211,703), the Recorder of Birmingham found as a question of 
fact that the premises could reasonably be expected to let from year to year at an amount equivalent to the sum of the weekly rents actually obtained. This being a question of fact onlyalthough a most unusual one-the Court of Appeal declined to interfere with it, and held that no deduction should be made from the aggregate of the weekly rents in respect of "voids and losses" (i.e., rent not paid whilst the premises were empty, or rent not recoverable from the tenant), or for the expense of collection; thus merely affirming the principle that "the test is not what the landlord actually receives, but what the tenant may reasonably be expected to give." The difference will probably vary not only in different rating areas, but even in the same area; and it will also vary with the class of property, so that no fixed proportion would apply to every case.

Where a house, built to be let by the year to one tenant, becomes through lapse of time, or altered circumstances, subdivided into tenements, the gross rent is always considerably more than the letting value of the tenement as an undivided whole. This increase is, of course, largely due to the greater cost of repairs (which should be allowed for as between gross and ratieable values), collection, and legal expenses (neither of which may be allowed). As a rule, however, the landlord would not care to let, nor would the tenant care to take the premises on anything longer than a weekly or monthly tenancy. A short tenancy ensures to the owner better control over the tenement, more punctual payment of rents, and less risk of vacancies ; whilst its advantage to the tenant lies in the fact that his tenure is sufficiently secure, whilst he can, should he so desire, change his residence at short notice to suit his work, \&c. The matter may perhaps be summed up thus: The owner demands a higher rent because he has to bear increased costs of collection, and, occasionally, legal charges-these are landlord's expenses, and cannot be allowed-but the tenant is willing to pay so much the more rent because he wishes to be able to leave when he chooses. Hence perhaps the landlord's collection and legal expenses may, generally speaking, be taken as the measure of the advantage, from the tenant's point of view, of a weekly or monthly over a yearly tenancy, and conversely, therefore, as the deduction to be made from the sum of the weekly or monthly rents to arrive at the gross yearly rent. This deduction, together with the sum required to produce the even pound, ten shillings, or whatever the unit of assessment may be, constitutes what is known as the "contingency balance." 
The second proposition we have laid down is equivalent to saying that the rateable value per shilling of rent should be lowest in the case of the smallest houses and increase gradually along (but not pari passu) with the rental value. The correctness of this general proposition is obvious; since not only will the cost of repairs, as a rule, decrease as the rent increases, but the legal expenses and the cost of collection will also, generally speaking, show a decline. Nevertheless, many assessment scales - even where the unit of assessment is as low as 5s.- - show an utter disregard for this elementary principle-generally in the direction of inflicting hardship on the owners of the lowest-rented properties. It is, of course, obvious that the higher the unit of assessment, the more difficult it is to construct a scale which will be equitable to the owners of all classes of weekly and monthly properties, and a certain amount of disregard for the above principle is unavoidable when the unit is made $10 \mathrm{~s}$. instead of the $5 s$. or even less, still frequently used in some districts. Where no fraction of $£ 1$ appears in the valuation lists, as in London, it is practically impossible to construct a scale which will be fair to everyone concerned; but, on the other hand, it is necessary to remember that, the higher the unit adopted, the less the clerical labour involved. When all the circumstances are considered, it is probable that the 10s. unit is the most suitable for cities and large towns. If the unit in country districts be fixed at $5 s$., the actual contingency balance obtained in a properly constructed scale will approximate very closely to the contingency balance aimed at. The gross rent of any weekly or monthly tenancy usually includes items outside the definition [Valuation (Metropolis) Act, 1869, section 4] of gross value, and, on the other hand, it sometimes excludes an item which, according to the decision in Pullen $v$. St. Saviour's Union ([1900] 1 Q.B. 138), should be included. The items outside the definition are :

(a) Rates. - The full rates which would be payable by the tenant, and not the net amount paid under a compounding arrangement by the landlord, should be deducted (Reg. $v$. Dodd (1865) L.R. 1 Q.B. 16), and they should be calculated on the rateable value, not on the rent received (Tyne Improvement Commissioners v. Chirton (1862) 32 L.J.M.C. 192). Rates include fishery rate (Reg. $v$. Smith (1885) 55 L.J.M.C. 49), sewers rate (Reg. v. Hall Dare (1864) 34 L.J.M.C. 17), and any other special rate.

(b) Water Rate.-This is, strictly speaking, not a rate at all, but may be compared to a charge for gas or any other neces- 
sary of life, and it is not rent in any sense (Smith $v$. Charchwardens of Birmingham, 1888). The question was before the Court as to whether the gross or the net charge was deductable, but it was not definitely decided.

(c) Taxes.-The land tax and the landlord's property tax are not included in these (Reg. v. Goodchild (1858) 27 L.J.M.C. 233), but inhabited house duty is. This tax is payable on houses of $£ 20$, and not exceeding $£ 40$ gross value, at the rate of $3 d$. in the $£$ on the gross value; over $£ 40$ and not exceeding $£ 60$ gross value at $6 d$. in the $£$; and over $£ 60$ gross value at $9 d$. in the $£$. It was held by the Court of Appeal that a block of dwellings should be assessed for inhabited house duty as one house (Attorney-General $v$. Mutual Tontine Westminster Chambers' Association (1876) 1 Ex.D. 469). The Board of Inland Revenue, however, as an act of grace, do not follow this decision strictly in the case of artisans' dwellings, but permit each self-contained tenement to be considered as a separate inhabited house (Report of Commissioners of Inland Revenue, 1886-87, p. 29, but see Customs and Inland Revenue Act, 1903, section 11). In the case of non-residential properties let on weekly or monthly tenancies, no deduction for inhabited house duty should, strictly speaking, be made, but as the duty in such instances, were the property residential, would generally be very trifling, the same assessment scales may usually be employed.

In Pullen $v$. St. Saviour's Union, the Court of Queen's Bench decided that, in order to arrive at the gross value, the cost of caretaker, dust removal, and watching, lighting, and cleaning the stairs and yard, must be added to the rent reserved; since this is "a sum which must be taken into consideration in arriving at the rent which a tenant might reasonably be expected to pay" for one of these tenements, the expenses forming part of those required to maintain the hereditament in a state to command the rent.

These expenses are sometimes met by a special charge per tenement per week in addition to the rent proper. Therefore, in assessing tenement houses, or artisans' dwellings, where the landlord undertakes the above-mentioned charges, it is necessary to add the special charge made for the performance of these functions to the gross rent proper, in order to arrive at the effective gross rent, and it is equally necessary to deduct the cost of performing the above services from the gross, to obtain the rateable value. 
Residential hereditaments let at weekly or monthly rents may be divided into the following classes :-

Class (A) Houses constructed for, and occupied by, one tenant.

Class (в) Houses constructed for occupation by one tenant, but sublet in either floors or rooms. This class we shall designate as "Tenement Houses."

Class (c) The house or block of residences constructed for occupation in separate tenements (i.e., artisans' dwellings).

\section{Class “A."}

Table "A" has been constructed, by means of the following formulæ, for the assessment of such properties :-

$$
G=\frac{n R(1-c)}{n+\frac{t}{20}} \text {, and } V=\frac{R(1-c)}{n+\frac{t}{20}} \text { where } n=\frac{1}{1-m} \text {, }
$$

where $V=$ rateable value,

and $G=$ gross value, or gross estimated rental,

,, $R=$ gross rent,

, $\quad c=$ contingency balance aimed at, expressed as a fraction of the gross rent,

," $m=$ deduction for maintenance, expressed as a fraction of the gross value or gross estimated rental,

, $\quad t=$ total poundage of rates on rateable value in shillings and fractions of a shilling (including both water-rate and inhabited house duty, expressed as poundage rates on the rateable value).

In order to turn inhabited house duty (which is leviable on the gross value) into the equivalent poundage rate on the rateable value, it is only necessary to multiply the poundage rate on the gross value by the value of " $n$."

If " $c$ " and " $m$ " are taken as percentages of the gross rent and gross value respectively, instead of as fractions, the above formulæ become

$$
G=\frac{n R(100-c)}{5(t+20 n)} \text {, and } V=\frac{R(100-c)}{5(t+20 n)}, \text { where } n=\frac{100}{100-m} .
$$

Mathematically correct results are obtained by these simple formulæ; and, with their aid, tables may be constructed, with the least possible expenditure of time and labour, for any values

No. 77.- vol. $\mathrm{xx}$. 
of the total poundage rate, contingency balance, and deduction for maintenance. Such tables should be computed in the first instance to the nearest shilling; then from these, suitable working tables may be quickly framed by adopting either five shillings, ten shillings, or one pound as the unit of assessment.

\section{Class “B."}

When a house constructed for a single occupier is sub-let in floors or rooms, the landlord, as we have already said, invariably obtains a higher rent than if it were let for the occupation of one tenant only. Such houses are always assessed in one of the three following ways :

(1) The rents of the individual lettings are added together, and the assessment based on the total.

This method is frequently adopted on account of its simplicity, but unless a deduction is made with the object of converting the sum of these tenemental rents into a figure which might fairly be supposed to represent the letting value of the house as if let to a single occupier, it produces a higher assessment than that laid down by statute. The reason for this is obvious; for it is an incontrovertible fact that the more tenants there are in a house the more will the total rent of that house exceed, in practically every instance, its letting value to a single tenant. It is this fact which, acting as a counterbalancing force to the principle that the contingency balance should be decreased as the rent of the tenement increases, has caused us to allow the same contingency balance throughout Table " $\mathrm{B}$," which is intended for the assessment of tenement houses.

When the gross value of such premises, arrived at by the above method, exceeds $£ 20$, the injustice of not reducing the sum of the rentals of the various tenements to the amount at which the premises would let to a single tenant becomes more glaring, because the owner has then to pay inhabited house duty, and is deprived of all compounding benefits.

Looking at the question from the economic point of view (i.e., the bad sanitary condition and unwholesome surroundings of such properties), it may perhaps be said that the owners of these premises deserve to bear a heavier burden of taxation than the statute imposes on them. However, so long as the law relating to the assessment of these houses remains unchanged, we cannot admit that the above argument ought to carry undue weight with rating authorities.

(2) The letting value of the house as if let to a single tenant 
is taken as the basis of assessment of the house as one undivided entity.

This is undoubtedly the right method wherever the front door and passages are within the landlord's control, and the tenants use certain parts of the premises in common. It is very difficult, however, to draw the line, in some instances, between these cases and those in which the landlord exercises partial control.

(3) The rental value of each letting as the basis of assessment of each tenement, considered as a separate rateable hereditament.

This last method is unquestionably the proper one in those cases where the landlord does not retain any control of the outer door, and does not occupy any part of the premises himself, or in the person of his servant. Hitherto "tenement houses" have been but seldom assessed in this way; but, in the recent case of Davis (on behalf of the Islington Borough Council) $v$. Wallis, it was laid down by the Divisional Court that this method should be adopted. This decision has, however, since been reversed by the Court of Appeal (White and Hales $v$. Mayor of Islington). It is, of course, clear that, if each letting is ever to be assessed as a separate hereditament, such a property should be valued by the scale (Table " $\mathrm{C}$ ") prepared for the assessment of artisans' dwellings, and not treated as Class "B" properties, for Table " $\mathrm{B}$ " assumes that the letting value to a single tenant is the proper basis of assessment for "tenement houses."

Premises coming under the category of Class " $B$ " require, in order to arrive at equitable results, a larger contingency balance than those comprised in Classes "A " or "C." It is exceedingly difficult to obtain satisfactory instances where precisely similar properties of this kind are let at weekly and yearly rents respectively, and no definite conclusions can be formulated from the instances which are available. It therefore becomes necessary to reduce the sum of the actual rents of the tenements by a certain amount in order to arrive at the fair letting value to a single tenant. This deduction, in the case of tenement houses, should clearly be considerably greater than that made as contingency balance in the case of small self-contained houses let on short tenancies. Again, in dealing with tenement houses, the decision in Pullen $v$. St. Saviour's Union must be remembered. We shall designate as "extra upkeep" the expenses referred to in that decision as coming under those "necessary to maintain the hereditament in a state to command the rent." Further, the footnote to the Third Schedule of the Valuation (Metropolis) Act of 1869 states that "the maximum scale of 
deductions shall not apply to houses or buildings let out in separate tenements." Hence, in dealing with "tenement houses," the deduction for maintenance is not limited to the fractions of the gross value laid down in that Statute.

Table "B" is intended to be used for the assessment of Class "B" properties (i.e., tenement houses), and it, or Tables with any desired values of " $c$," " $m$," " $e$," and " $t$," can be constructed from the following formulæ: Let $V, G, R, c, m$, and $t$ represent the same as before, and let " $e$ " represent the "extra upkeep" expressed as a percentage of the gross rent; " $c$ " and " $m$ " being also given in percentages :-

$$
\text { Then } G=\frac{n R\left(100-c+\frac{e t}{20}\right)}{5(20 n+t)} \text {, and } V=\frac{R(100-c-n e)}{5(20 n+t)} \text {, }
$$

where

$$
n=\frac{100}{100-m},
$$

If " $c$," " $m$," and " $e$ " are taken as fractions, instead of as percentages, the above formulæ become

$$
G=\frac{20 n R\left(1-c+\frac{e t}{20}\right)}{t+20 n} \text {, and } V=\frac{20 R(1-c-n e)}{t+20 n} \text {, where } n=\frac{1}{1-m} \text {. }
$$

and if we put $e=o$ in either formula, we revert to that given for self-contained houses.

\section{Class "C."}

This class of property is of the nature of artisans' dwellings where, following the decision in Reg. v. St. George's Union, each tenement must be assessed separately. The contingency balance and deduction for maintenance should be the same as those allowed in the case of self-contained houses (Class "A ") let on weekly and monthly tenancies. Hence Table "A" may also be used for artisans' dwellings, provided that there is no "extra upkeep." As, however, there almost invariably is "extra upkeep" in these cases, Table " $\mathrm{C}$ " has been framed by means of the formulæ just given for computing Table "B," but with a smaller contingency balance and deduction for maintenance, both of which are lessened as the rental value increases. The total deduction in the case of artisans' dwellings is not limited in the metropolis to the maximum deduction for ordinary houses (Western $v$. Kensington Assessment Committee, 1907), and, consequently, the "extra upkeep" may be added to the deduction for ordinary maintenance.

Tables "A," "B," and " $\mathrm{C}$ " have been computed to the nearest 
shilling, so that working scales can be at once compiled from them with equal readiness, no matter whether the unit of assessment be taken as $5 s ., 10 s ., £ 1$, or any other sum. If Tables " $\mathrm{A}$," "B," and " $\mathrm{C}$ " had been presented as working Tables, they would only have been applicable for the particular unit of assessment for which they were computed.

\section{SPecimen of TABLE “A."}

For the assessment of ordinary weekly and monthly tenancies (Class " $A$ " properties), giving the gross and rateable values to the nearest shilling.

\begin{tabular}{|c|c|c|c|c|c|c|}
\hline \multirow{2}{*}{$\begin{array}{l}\text { Contingency } \\
\text { balance. }\end{array}$} & \multirow{2}{*}{$\begin{array}{c}\text { Deduction } \\
\text { for } \\
\text { maintenance. }\end{array}$} & \multirow{2}{*}{$\begin{array}{l}\text { Weekly } \\
\text { rent. }\end{array}$} & \multicolumn{2}{|c|}{ Rates, 3/-. } & \multicolumn{2}{|c|}{ Rates, 11/6. } \\
\hline & & & G. V. & R. V. & G. V. & R. V. \\
\hline $10 \%$ & $25 \%$ & $\left\{\begin{array}{cc}s . & d . \\
1 & 0 \\
\text { to } & 0 \\
5 & 0\end{array}\right.$ & $\begin{array}{rr}£ & s . \\
2 & 2 \\
10 & 10\end{array}$ & 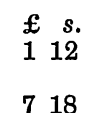 & $\begin{array}{rr}£ & s . \\
1 & 13 \\
8 & 3\end{array}$ & $\begin{array}{ll}£ & s . \\
1 & 5 \\
6 & 3\end{array}$ \\
\hline $7 \frac{1}{2} \%$ & $22 \frac{1}{2} \%$ & $\left\{\begin{array}{c}5 \text { to } \\
100\end{array}\right.$ & $\begin{array}{l}1117 \\
2111\end{array}$ & $\begin{array}{rr}9 & 4 \\
16 & 14\end{array}$ & 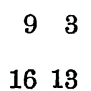 & $\begin{array}{rr}7 & 2 \\
12 & 18\end{array}$ \\
\hline $5 \%$ & $20 \%$ & $\begin{cases}11 & 0 \\
\text { to } & 0 \\
20 & 0\end{cases}$ & $\begin{array}{ll}24 & 5 \\
44 & 2\end{array}$ & $\begin{array}{ll}19 & 8 \\
35 & 6\end{array}$ & $\begin{array}{ll}18 & 12 \\
33 & 17\end{array}$ & $\begin{array}{lr}14 & 18 \\
27 & 1\end{array}$ \\
\hline
\end{tabular}

SPECIMEN OF TABLE "B."

For the assessment of "tenement houses" (Class "B" properties), giving the gross and rateable values to the nearest shilling.

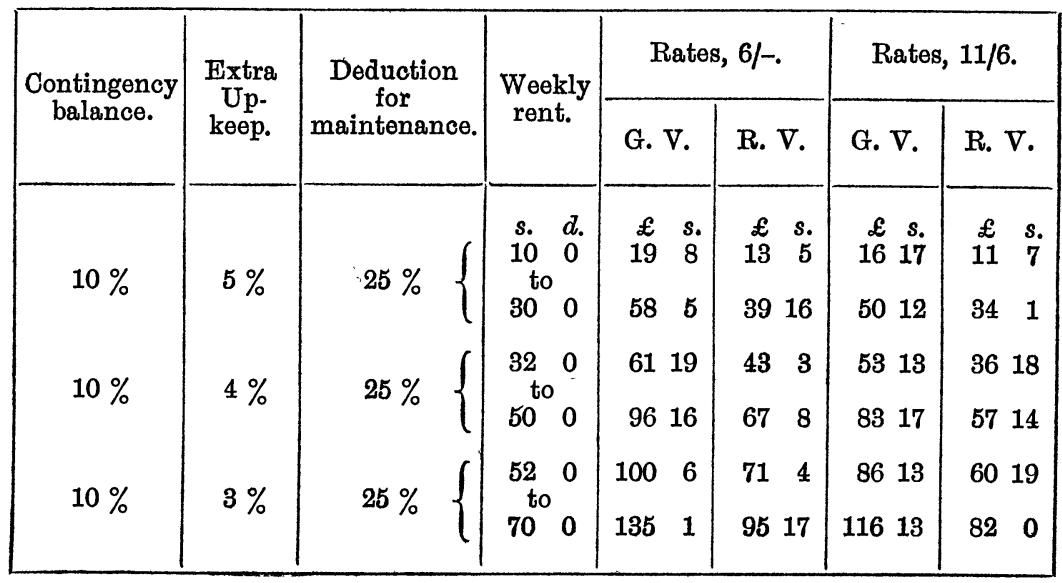




\section{Specimen of Table "C."}

For the assessment of artisans' dwellings (Class " $C$ " properties), giving the gross and rateable values to the nearest shilling.

\begin{tabular}{|c|c|c|c|c|c|c|c|}
\hline \multirow{2}{*}{$\begin{array}{l}\text { Contingency } \\
\text { balance. }\end{array}$} & \multirow{2}{*}{$\begin{array}{c}\text { Extra } \\
\text { Up- } \\
\text { keep. }\end{array}$} & \multirow{2}{*}{$\begin{array}{c}\text { Deduction } \\
\text { for } \\
\text { maintenanoe. }\end{array}$} & \multirow{2}{*}{$\begin{array}{l}\text { Weekly } \\
\text { rent. }\end{array}$} & \multicolumn{2}{|c|}{ Rates, 4/-. } & \multicolumn{2}{|c|}{ Rates, 11/6. } \\
\hline & & & & G. V. & R. $\nabla$. & G. V. & R. V. \\
\hline $10 \%$ & $5 \%$ & $25 \%$ & $\begin{array}{ll}\text { s. } & d . \\
1 & 0 \\
\text { to } & \end{array}$ & $\begin{array}{ll}£ & s . \\
2 & 1 \\
10 & 6\end{array}$ & $\begin{array}{ll}£ & s . \\
1 & 8 \\
7 & 1\end{array}$ & $\begin{array}{lll}2 & s . \\
1 & 14 \\
8 & 9\end{array}$ & $\begin{array}{ll}£ & s . \\
1 & 3\end{array}$ \\
\hline $7 \frac{1}{2} \%$ & $4 \%$ & $22 \frac{1}{2} \%$ & $\begin{array}{c}5 \quad 6 \\
\text { to } \\
10 \quad 0\end{array}$ & $\begin{array}{lr}11 & 11 \\
21 & 0\end{array}$ & $\begin{array}{rr}8 & 8 \\
15 & 5\end{array}$ & $\begin{array}{rr}9 & 8 \\
17 & 1\end{array}$ & $\begin{array}{rr}6 & 14 \\
12 & 3\end{array}$ \\
\hline
\end{tabular}

F. Oliver Lyons 